\title{
THE AGENCY THEORY OF THE ATTORNEY- CLIENT RELATIONSHIP: AN IMPROPER JUSTIFICATION FOR HOLDING CLIENTS RESPONSIBLE FOR THEIR ATTORNEYS' PROCEDURAL ERRORS
}

\section{INTRODUCTION}

For many years, courts and commentators have struggled with the question of who-attorney or client-should bear the penalty for an attorney's errors. ${ }^{1}$ During the twentieth century, courts have often resolved the question in cases involving an attorney's procedural errors ${ }^{2}$ by resorting to the agency theory of the attorney-client relationship. In 1962, the Supreme Court, in Link v. Wabash Railroad, explained this rationale for holding chents responsible for their attorneys' procedural abuses:

1. Compare Chisler v. Randall, 124 Kan. 278, 259 P. 687 (1927) (client not responsible for unauthorized defamatory statements of attorney) and Welsl v. Cochran, 63 N.Y. 181 (1875) (attorney's general autliority will not render client liable for damages caused by attomey's act of wrongfully directing levy upon goods) with Fairbanks v. Stanley, 18 Me. 296 (1841) (attorney's general authority to commence suits will render client liable for damages caused by attorney wrongfully attacling property) and Vauglin v. Fisher, 32 Mo. App. 29 (1888) (client's special direction to attorney not required to render client responsible for attorney's act of wrongfully obtaining sale order). See generally Note, Mistakes of Law, 10 U. KAN. L. REv. 615 (1962) (supporting trend toward vacating judgments when attorney's reasonable mistake of law results in judgment against client); Note, Civil Procedure-Power of Federal Courts to Discipline Attorneys for Delay in Pre-trial Procedure, 38 NOTRE DAME LAw. 158 (1963) (arguing that rationale of Link v. Wabasli R.R., 370 U.S. 626 (1962), is unfair to innocent clients); Note, Dismissal for Failure to Attend a Pretrial Conference and the Use of Sanctions at Preparatory Stages of Litigation, 72 YALE L.J. 819 (1963) (same).

2. This Note attempts to make an essential distinction between procedural and substantive conduct. Procedural conduct is any conduct directly related to the management of a suit in accordance with a court's rules of procedure. See 2 F. MECHEM, A TREATISE ON THE LAW OF AGENCY $\S 2160$ (2d ed. 1914). In other words, procedural conduct is conduct that is either directed toward the court (e.g., appearing at learings and conferences and filing pleadings) or directed toward the opposing party under close supervision of the court (e.g., discovery). In contrast, substantive conduct is directed toward the opposing party or a third party without the supervision of the court (e.g., settlement offers and transactional work). $C$. $i d$. For example, substantive conduct includes the decision to bring a suit, but the drafting and filing of a complaint is procedural conduct. See Buehman v. Smelker, 50 Ariz. 18, 19, 68 P.2d 946, 950-51 (1937) (attorney controls drafting of pleadings). The courts' definition of attorney authority also reflects tle substance/procedure distinction. See infra note 36 and accompanying text. 
There is certainly no merit to the contention that dismissal of petitioner's claim because of his counsel's unexplained conduct imposes an unjust penalty on the client. Petitioner voluntarily chose his attorney as his representative in the action, and he cannot now avoid the consequences of the acts or omissions of this freely selected agent. Any other notion would be wholly inconsistent with our system of representative litigation, in which each party is deened bound by the acts of his lawyer-agent and is considered to have "notice of all facts, notice of which can be charged upon the attorney." 3

This Note challenges the Supreme Court's assertion that the agency theory is the only "notion" consistent with our judicial system. The Note argues that the agency theory mischaracterizes the attorney-client relationship and is simply inconsistent with many policies that our judicial system holds important. ${ }^{4}$ The theory shonld have no place in the courts' calculus for tailoring sanctions for an attorney's procedural error. Instead, courts should rely completely and openly on an analysis of the policies behind their sanctioning power.

This Note first examines the fairly recent historical development of the agency theory as a rationale for sanctioning chients for their attorneys' procedural errors. ${ }^{5}$ Next, it examines the agency theory's mcompatibility with the implications of the substance/procedure distimction in attorney authority. ${ }^{6}$ The Note then demonstrates the agency theory's imconsistency with the policy considerations that support dismissal for want of prosecution ${ }^{7}$ and discovery abuse. ${ }^{8}$ Fimally, the Note describes the policy concerns that should inform all decisions to impose sanctions for discovery abuse or want of prosecution. ${ }^{9}$

3. 370 U.S. 626, 633-34 (1962) (citing Smith v. Ayer, 101 U.S. 320, 326 (1879)).

4. See infra notes 46-58, 66-81, and accompanying text. Most courts have reacted to these inconsistencies in one of two ways. Some courts have expressly limited the Link decision. See, e.g., Carter v. Albert Einstein Medical Center, 804 F.2d 805, 807-08 (3d Cir. 1986). Others have ordered sanctions inconsistent with the rcal policies underlying the sanctioning power. See, e.g., Damiani v. Rhode Island Hosp., 704 F.2d 12, 16 (1st Cir. 1983) (dismissing innocent client's claim although goal of deterring discovery abuse would be furthered only by sanctioning attorney); see also infra notes 67-81 and accompanying text (discussing appropriateness of dismissal in light of deterrence objective). Some courts, however, have not responded to the inconsistency inherent in the agency theory and continue to follow Link. The First Circuit's most recent decisions have sanctioned clients, based both on client negligence and on the agency theory. See Townsend v. Gray Line Bus Co., 767 F.2d 11, 19 (1st Cir. 1985); Damiani, 704 F.2d at 16-17. However, strong language in those decisions approving the agency theory and the outcomes of earlier cases, e.g., Corchado v. Puerto Rico Marine Mgmt., Inc., 665 F.2d 410, 413 (1st Cir. 1981) (no client fault required for client sanction), cert. denied, 459 U.S. 826 (1982), indicate that the court will adhere to Link. See also infra note 28 and accompanying text.

5. See infra notes 10-32 and accompanying text.

6. See infra notes $33-44$ and accompanying text.

7. See infra notes $46-62$ and accompanying text.

8. See infra notes $63-93$ and accompanying text.

9. See infra notes 94-111 and accoinpanying text. 


\section{A BRIEF History OF tHe AgENCY THEORY OF THE ATtORNEY- Client RELATIONSHIP}

\section{A. The Early English and American Approach.}

It is difficult to determine precisely when courts began using the agency theory to sanction clients for their attorneys' procedural errors. ${ }^{10}$ Very early Enghish cases indicate that on matters of procedure, the client would not be responsible for the words and conduct of his attorney unless he avowed them. ${ }^{11}$ Although traces of the practice of avowal remain as late as the early nineteenth century, ${ }^{12}$ Enghish courts quickly began holding non-avowing chients responsible for their attorneys' substantive, ${ }^{13}$ and on occasion even procedural, ${ }^{14}$ misconduct.

Despite this increased identification of attorneys with chents, English courts remained reluctant to hold completely innocent chents responsible for their attorneys' procedural errors. For exaunple, in the eighteenth and nineteenth centuries, Enghish courts allowed cases to proceed after an attorney's delay on condition that the attorney personally pay the costs of delay. ${ }^{15}$ These decisions did not address agency consid-

10. Although a number of early American courts dismissed cases based on attorneys' procedural errors, they did not use an agency theory as their rationale. See, e.g., Thompson v. Thompson, 3 N.C. (2 Hayw.) 357, 357 (1806) (nonsuit for failure to offer original bill of sale affirmed on grounds of negligence); Wright $v$. Thomas, 6 Tex. 420 (1851) (dismissal for failure of attorney to appear at trial found appropriate without discussion); see also Butler v. Butler, 1 Root 275 (Com1. 1791) (sanctity of record requires that chent be bound by attorney's conduct in court).

11. See, e.g., Bygot v. Belet, Y.B. 3 Edw. II 3, fo. 43 a (1310), reprinted in 20 SELDEN SOcIETY 128,129 (1905) (attorney's pleading must be avowed by client before it becomes effective and binding); see also Holmes, Agency, 5 HARV. L. REv. 1, 6 (1891) (in very early English cases, party could "avoid the loss of his suit . . . by disavowing the pleading of his advocate").

12. See Colledge v. Horn, 3 Bimg. 119, 121, 130 Eng. Rep. 459, 460 (C.P. 1825) ("I cannot allow that the counsel is the agent of the party."). Colledge is consistent with the ratification principle of Bygot. The court in Colledge granted a new trial to establish whether the client was within hearing distance of his counsel's statement at trial, thus implying that an attorney's statement at trial is not bindiug on the client unless authorized by the client. Colledge, 3 Bing. at 121, 130 Eng. Rep. at 460 .

13. See, e.g., Tunstall v. Trappes, 3 Sim. 286, 307, 57 Eng. Rep. 1005, 1013 (Ch. 1829) (notice to attorney of judgunent against estate is actual notice to chent-purchaser); Wimter v. Lord Anson, 3 Russ. 488, 493, 38 Eng. Rep. 658, 660 (Ch. 1878) (notice to attorney of hen against property is constructive notice to client-mortgagee).

14. See, e.g., Pisani v. Lawson, 7 L.J.C.P. 144, 144 (1838) (attorney's consent to opposing party's joinder of pleas biuds client); Latuch v. Pasherante, 1 Salk. 86, 86, 91 Eng. Rep. 81, 81 (K.B. 1697) (same). Although the reasons for this change are not clear, the practice of avowal may have been a response to the poor quality of early legal representation, a response that became unnecessary as lawyers improved their skills. See $4 \mathrm{Hen} .4$, ch. 18 (1402) (statute regulating practice of attorneys in response to "great Number of Attornies, ignorant and not learned in the Law, as they were wont to be before this Time").

15. E.g., Townley v. Jones, 8 C.B.N.S. 288, 289, 141 Eng. Rep. 1177, 1177 (C.P. 1860) (allowing case to proceed on condition that attorney pay costs of failure to attend trial); Doe v. Roe, 1 L.J.K.B.O.S. 154, 154 (1823) (same); De Roufigny v. Peale, 3 Taunt. 484, 128 Eng. Rep. 192 (C.P. 
erations; rather, the courts dealt exphicitly with such pohicy considerations as deterrence and protecting the opponent's interests. ${ }^{16}$

Like English courts, American courts allowed cases to proceed after finding a want of prosecution. ${ }^{17}$ The American courts, however, imposed the costs of delay on the "party" in whose name the delay occurred, not allocating blame between attorney and chent. ${ }^{18}$ Although these early American cases arguably first apphed the agency theory to the attorneyclient relationship, none of thein used an agency theory to justify imposing costs on the client. ${ }^{19}$ Courts did not resort to the agency theory for that purpose until the late nineteenth century. ${ }^{20}$

\section{B. Emergence of the Agency Theory.}

Between the early inineteenth and mid-twentieth centuries, the legal characterization of the attorney-client relationship changed in a way that encouraged courts to hold clients responsible for their attorneys' procedural errors. The change originated in a line of mid-nineteenth century cases that considered the client and attorney the sane entity with regard to the client's notice of substantive facts. ${ }^{21}$ Courts soon went beyond conclusively presuming a chent's notice and established a second conclusive presumption of a client's responsibility for an attorney's negh-

1811) (granting new trial on condition that attorney pay costs occasioned by failure to deliver brief to opposing counsel); Ex parte Smith, 1 Atk. 139, 26 Eng. Rep. 90, 91 (Ch. 1742) ("I by no means like this practice [of intentional delay], and it is what attornies [sic] in the country are very apt to fall into; but if they make a custoin of it, I shall, for the future, order the costs of the affidavit to come out of their own pockets.").

16. See Doe v. Roe, 1 L.J.K.B.O.S. at 154.

17. E.g., Jackson v. Waldron, 5 F. 245, 247-48 (C.C.W.D. Tem. 1880) (setting aside nonsuit on grounds of attorney's mistake about competency of evidence, on condition that plaintiff pay costs); Rogers v. Garrison, 2 Cai. R. 379, 379 (N.Y. Sup. Ct. 1805) (denying motion for nonsuit based on attorney's failure to appear at trial, on condition that party at fault pay costs); Jackson $v$. Brown, 1 Cai. R. 152, 152 (N.Y. Sup. Ct. 1803) (same).

18. See, e.g., Waldron, 5 F. at 247-48 ("the plaintiff will pay all costs of the suit"); Brown, 1 Cai. R. at 152 ("the plaintiff must pay the costs of not proceeding to trial").

19. Rather than attempting to sanction the person at fault, these cases were concerned with protecting thc opposing party and reaching the merits of the plaintiff's claim. See, e.g., Waldron, 5 F, at 247 ("no injury can result to the defendant by re-installing this [case], which is obviously a suit of merit by the plaintiff"); Brown, 1 Cai. R. at 152 (sudden illness of plaintiff and attorney acceptable excuse for delay but plaintiff must pay costs).

20. Compare Nash v. Gilkeson, 5 Serg. \& Rawle 352, 354 ( $\mathrm{Pa} .1819)$ (court rule requiring that notice of deposition be given to party not satisfied by notice given to attorney) with Smith v. Ayer, 101 U.S. 320, 326 (1879) ("The law . . . considers the [chent] as affected with notice of all facts, notice of which can be charged upon the attorney.").

21. E.g., Smith, 101 U.S. at 326 (imputing to chent-principal his attorney's knowledge that third party held note as executor); Bierce v. Red Bluff Hotel Co., 31 Cal. 161, 167 (1866) (conclusive presumption that attorney will communicate all facts to chent); Williams v. Tatnall, 29 Ill. 553, 564 (1863) (same). 
gence. $^{22}$ Without distinguishing between substantive and procedural matters, courts thus began "deal[ing] with parties as though they were actually present in the person of their solicitors and as though they knew all their solicitors knew."23

For most of the twentieth century, the agency theory has enjoyed nearly uniform acceptance in the United States. ${ }^{24}$ American courts have confidently accepted the proposition that "[a]ny other principle in the conduct of causes would be exceedingly impracticable."25 Following this tradition, the Supreine Court in 1962 decided the landmark case of Link v. Wabash Railroad. In Link, the plaintiff's attorney failed to attend a pretrial conference and the Court affirmed a dismissal of the complaint, justifying the harsh result by resort to the agency theory. ${ }^{26}$

\section{Present Status of the Agency Theory.}

Despite the bold and broad language of the Link opinion, the agency theory no longer enjoys unanimous support in the procedural context. ${ }^{27}$ Although First Circuit decisions follow both the letter and

22. See, e.g., Nicol v. City of San Francisco, 130 Cal. 288, 290, 62 P. 513, 514 (1900) ("The counsel's negligence is [the client's] negligence . . . ."); Butler v. Morse, 66 N.H. 429, 430-31, 23 A. 90, 91 (1891) (same) (citing Bierce and Williams); Chambers v. Hodges, 23 Tex. 105, 110 (1859) (attorney's conduct, even in disobedience of client's instructions, binds chient with respect to third persons).

23. Chadwick v. Parkhill Corp., 16 Del. Ch. 105, 110, 141 A. 823, 825 (1928); see also Gifford v. Thorn, 9 N.J. Eq. 702, 722 (1855) (party appears before court through attorney). Interestingly, althougli English courts liave become inore willing to hold clients responsible for their attorneys' procedural errors, they have not adopted tlie agency theory. See, e.g., Allen v. Sir Alfred McAlpine \& Sons, [1968] 2 Q.B. 229, 243-46 (Denning, M.R.) (disunissal of client's claim for attorney's failure to diligeutly prosecute based on explicit evaluation of policy concerns).

24. See, e.g., Laird v. Air Carrier Eugine Serv., Inc., 263 F.2d 948, 953 (5tlı Cir. 1959) (attorney considered simply as "any other agent"); Rotlınan v. Wilson, 121 F.2d 1000, 1006 (9th Cir. 1941) (relationship betweeu attomey and client couclied in terms of agency); see also Note, Financial Penalties Imposed Directly Against Attorneys in Litigation Without Resort to the Contempt Power, 26 UCLA L. REV. 855, 866 (1979).

25. Chadwick, 16 Del. Ch. at 110, 141 A. at 825 .

26. 370 U.S. 626, 634-36 (1962); see supra text accompanying note 3 .

27. Different jurisdictions take very different approaclies to apportioning sanctions between attorney and client. Several continue to adhere rigidly to Link. See, e.g., First Bank v. Carswell, 111 Ill. App. 3d 71, 73, 443 N.E.2d 755, 757 (1982) (default judgment appropriate, despite innocence of client, when attorney failed to notify client of court date); Iuternational Vacuuin, Iuc. v. Owens, 439 N.E.2d 188, 189-90 (Ind. Ct. App. 1982) (default judgment appropriate when attorney failed to notify court of changed address and subsequently failed to receive notice of pretrial liearing); Vanhook v. Stanford-Lincohi County Rescue Squad, Inc., 678 S.W.2d 797, 799-800 (Ky. Ct. App. 1984) (negligence of attorney in failing to appear at trial imputable to client and grounds for dismissal); Kiefer v. Great Atlantic and Pacific Tea Co., 80 Micll. App. 590, 593-94 \& n.4, 264 N.W.2d 71, 73-74 \& n.4 (1978) (notice given to attorney requiring client to appear at settlemeut conference constitutes notice to client).

Other jurisdictions seem to have abandoned the agency rationale of Link. See, e.g., Battryn v. Indian Oil Co., 472 A.2d 937, 942 (Me. 1984) (court has inherent authority to sanction attorney for 


\section{spirit of $\operatorname{Link}^{28}$ the Third Circuit seems to follow neither. ${ }^{29}$ Such dis-}

discovery abuse); Beit v. Probate and Family Court Dep't, 385 Mass. 854, 859-60 \& n.11, 434 N.E.2d 642, 646 \& n.11 (1982) (attorney who failed to appear at trial should be sanctioned because "it is unfair and unjust to impose the punishment, for the lawyer's failure to appear, on a chent"); Moran v. Rynar, 39 A.D.2d 718, 719, 332 N.Y.S.2d 138, 141 (1972) (attorney's failure to file note of issue "should not deprive his client of his day in court"); Simmons v. Tuttle, 70 N.C. App. 101, 105, 318 S.E.2d 847, 849 (1984) (dismissal for want of prosecution improper when client not at fault "because an attorney's neglect will not be imputed to a hitigant that is himself free of fault"); Drescher v. Summers, 30 Ohio App. 3d 271, 272-73, 507 N.E.2d 1170, 1172 (1980) (requirement that party be served with notice prior to dismissal for want of prosecution not satisfied by notice to attorney). Although none of these jurisdictions have actually overruled cases that employ the agency theory, their approaches reflect either a de facto abandonment of the theory or the use of a fairness exception that drains the theory of its vitality.

Other jurisdictions follow various middle roads. For example, the District of Columbia Court of Appeals will impute an attorney's ordinary negligence to the client, but will not impute gross negligence. See Lynch v. Meridian Hill Studio Apts., Inc., 491 A.2d 515, 519 \& n.8 (D.C. 1985); Bond v. Wilson, 398 A.2d 21, 24 (D.C. 1979). This approach offers an interesting comparison to the approach followed in Pennsylvania. In that state, if there is a reasonable explanation for the attorney's neglect, then the negligence will not be imputed to the client. Alston v. Philadelphia Elec. Co., $337 \mathrm{~Pa}$. Super. 46, 56-57, 486 A.2d 473, 478 (1984). A court attempting to follow beth approaches could not impute either gross or slight negligence. These approaches are a far cry from Link and traditional agency law.

Finally, some jurisdictions do not adliere consistently to any approach. See, eg., Thode v. Thode, 190 Conn. 694, 698-99, 462 A.2d 4, 6-7 (1983) (recognizing that court may follow Link and hold client responsible or may sanction attorney directly). Compare Zaccardi v. Becker, 162 N.J. Super. 329, 331-32, 292 A.2d 1220, 1222 (despite innocence of client, deterrent goal of discovery rules requires dismissal), cert. denied, 79 N.J. 464, 401 A.2d 221 (1978) with Jansson v. Fairleigh Dickinson Univ., 198 N.J. Super. 190, 194-96, 486 A.2d 920, 922 (1985) (court should not dismiss for discovery abuse unless client negligent or opposing party would be prejudiced).

28. See Farm Constr. Servs., Inc. v. Fudge, 831 F.2d 18, 21 (1st Cir. 1987) (per curiam) (citing Link and affirming dismissal despite client's claim of innocence); Townsend v. Gray Line Bus Co., 767 F.2d 11, 19 (1st Cir. 1985) (attorney's failure to appear at post-trial conference decmed waiver of party's right to new trial); Damiani v. Rhode Island Hosp., 704 F.2d 12, 16-17 (1st Cir. 1983) (disinissal for failure to comply with discovery order despite lack of evidence of client fault); Corchado v. Puerto Rico Marine Mgmt., Inc., 665 F.2d 410, 413 (1st Cir. 1981) (dismissing claim for attorney's failure to comply with discovery order is "an unavoidable side effect of the adversary system"), cert. denied, 459 U.S. 826 (1982); see also supra note 4.

29. See Carter v. Albert Einstein Medical Center, 804 F.2d 805, 807-08 (3d Cir. 1986). The Carter court reaffirmed the validity of Link. Nevertheless, it stated that it did not favor disımissal of a case for attorney errors and applied a four-part test of responsibility, establislied in Poulis v. State Farm Fire \& Casualty Co., 747 F.2d 863, 868 (3d Cir. 1984), that severely limited Link Carter, 804 F.2d at 807-08; see also Regional Refuse Systems, Inc. v. Iuland Reclamation Co., 842 F.2d 150, 153 (6th Cir. 1988) (citing Carter with approval and stating "this circuit has been more ready than others to reverse dismissals ... especially when it appears that the party is blameless").

The Third Circuit appears to have drifted even further from Link in a recent case, Dunbar v. Triangle Lumber \& Supply Co., 816 F.2d 126 (3d Cir. 1987). In Dunbar, as in Link, an attorney failed to appear at several pretrial conferences. Id. at 127-28. The district court dismissed for want of prosecution under FED. R. CIv. P. 41(b). Dunbar, 816 F.2d at 128. The Third Circuit vacated the dismissal, creating a new procedural requirement of direct notice to the chent prior to dismissal. Id. at 129. The court reached its decision by focusing on the personal responsibility test of Poulis and Carter and ignoring the agency considerations of Link. Id. at 128-29; see also Curtis T. Bedwell \& Sons v. International Fidelity Ins. Co., 843 F.2d 683, $691-93$ (3d Cir. 1988) (applying the Poulis test to district court's dismissal for failure to comply with discovery requests, and finding chient 
agreements among authorities on the agency issue are not uncommon and have led to inconsistent decisions. For example, in Knight v. Davis, ${ }^{30}$ the defendant's attorney withdrew from the case without informing his client of the trial date. When the client failed to appear at trial, the trial court entered a default judgment. The Alabama Supreme Court held that the normal presumption of communication did not apply and remanded the case for trial. ${ }^{31}$ In McNally $v$. Stonehenge, Inc, however, a factually identical case, the Georgia Supreme Court affirmed a default judgment, holding simply that notice to tlie attorney constituted notice to the chient. ${ }^{32}$

Such inconsistencies have resulted because the agency theory reflects an inaccurate view of the attorney-client relationship and thus fails to command consistent acceptance. The next part of this Note explores contradictions between the agency theory and widely lield ideas about the division of authority in the attorney-client relationship.

\section{A Comparison of the Agency Theory with CONCEPTIONS OF ATTORNEY AUTHORITY}

Courts and commentators have frequently considered the attorney's authority im the attorney-client relationship. ${ }^{33}$ This material shows that the agency theory is inconsistent witl generally accepted characterizations of that relationship.

As part I of this Note points out, courts have often held clients responsible for their attorneys' procedural mistakes. ${ }^{34}$ Yet, courts have held that an attorney has virtually unrestrained authority to act in procedural or tactical areas. ${ }^{35}$ Indeed, most jurisdictions continue to distin-

personally responsible); Grant v. Clairol, Inc., 113 F.R.D. 574, 577-78 (E.D. Pa. 1986) (dismissing claim for failure to comply with discovery order based on analysis similar to that used in Dunbar).

The Fourth Circuit has drifted yet further from Link. A Fourth Circuit panel, consisting of Circuit Judges Hall and Wilkinson and District Judge Bullock, recently held that a client's innocence qualifies as "mistake" or "excusable neglect" for purposes of FED. R. CrV. P. 60(b)(1) and that "[w] be set aside." Augusta Fiberglass Coatings v. Fodor Contracting, 843 F.2d 808, 811 (4th Cir. 1988) (per curiam). But see Lolatchy v. Arthur Murray, Inc., 816 F.2d 951, 956 (4th Cir. 1987) (Wilkinson, J., dissenting) (citing "general rule" that attorney delay and neglect should be imputed to the client).

30. 356 So. 2d 156 (Ala. 1978).

31. Id. at 157-58.

32. 242 Ga. 258,248 S.E.2d 653 (1978).

33. See infra notes $35-39$ and accompanying text.

34. See supra notes $3,23-32$, and accompanying text.

35. See, e.g., Moulton v. Bowker, 115 Mass. 36, 40 (1874) ("An attorney at law has authority, by virtue of his employment as such, to do in behalf of his client all acts, in or out of court, necessary or mcidental to the prosecution and management of the suit ...."); Averill v. Williams, 4 Denio 295, 296 (N.Y. Sup. Ct. 1847) ("An attorney has very plenary [sic] power in the prosecution of a suit to 
guish between procedural matters, in which the attorney has authority, and substantive decisions, in which the chent has authority. ${ }^{36}$

This distinction is consistent with research on the actual allocation of authority in the attorney-chent relationship. ${ }^{37}$ Moreover, because the traditional distinction posits that the input of the client-a layperson unable to understand the procedural aspects of a case-is of no value in connection witl procedural issues, ${ }^{38}$ courts liave often held that an attorney may exercise discretion in procedural matters and may even take actions contrary to a client's instructions. ${ }^{39}$

The substance/procedure distinction, lowever, does not support the conclusion that an attorney is the agent of her client in procedural matters. According to traditional agency law, an agency relationship exists

judgment and execution ...."); Huston v. Mitchell, 14 Serg. \& Rawle 307, 309 (Pa. 1826) (attorney fully authorized "to do such things as pertained to the conducting of the suit"); Swinfen v. Chelmsford, 5 Hurl. \& Norm. 890, 922, 157 Eng. Rep. 1436, 1449 (Ex. 1860) ("[A] counsel has complete authority over the suit, the mode of conducting it, and all that is incident to it.").

36. See Valley Line Co. v. Ryan, 771 F.2d 366, 376 (8th Cir. 1985) (filing stipulations is procedural matter within implied authority of attorney); Blanton v. Wounancare, Inc., $38 \mathrm{Cal}$. 3d 396, 403-04, 696 P.2d 645, 650, 212 Cal. Rptr. 151, 155-56 (1985) (attorney has authority to make stipulations or agreenents regarding procedure); Hallock v. State, 64 N.Y.2d 224, 230, 474 N.E.2d 1178, 1181,485 N.Y.S.2d 510, 513 (1984) (conclusion of settlement agrecment not within attorney's authority over procedural matters); see also Model Rules of Professional Conduct Rule 1.2 comment 1 (1983) [hereinafter MODEL RULES] (distinguishing between "objectives" and "means").

In the criminal context, compare Rced v. Ross, 468 U.S. 1, 13 (1984) ("absent exceptional eircumstances, a defendant is bound by the tactical decisions of competent counsel") with Jones v. Barnes, 463 U.S. 745, 751 (1983) ("accused has the ultimate authority to make certain fundamental decisions regarding the case"). See also Pcople v. McKenzie, 34 Cal. 3d 616, 631 n.9, 668 P.2d 769, 779 n.9, 194 Cal. Rptr. 462, 472 n.9 (1983) ("Of course, substantive decisions as to what plea to enter, whether to waive jury trial, and whether to testify are ultimately to be made by the defendant after consultation with counsel.").

37. Most commentators have concluded that in the typical attorney-client relationship, the attorney exercises almost complete discretion in procedural matters. See, e.g., D. ROSENTHAL, LAWyer and Client: Who's in Charge? 30-34 (1974); Mallor, Punitive Attorneys' Fees for Abuses of the Judicial System, 61 N.C.L. REv. 613, 651 (1983).

38. Martyn, Informed Consent in the Practice of Law, 48 Geo. WASH. L. Rev. 307, 315 (1980). For an example of the traditional view, see G. ARCHER, ETHICAL OBLIGations of THE LAWYER $\S 31$ (1910) (explaining too fully to client the necessary legal steps serves "no useful purpose").

39. See, e.g., Eury v. Huff, 141 F.2d 554, 555 (4th Cir. 1944) (attorney has authority to control procedural matters independent of client); Buehman v. Smelker, 50 Ariz. 18, 29, 68 P.2d 946, 950-51 (1937) (attorney, as independent contractor rather than servant, controls drafting of pleadings); Duffy v. Griffith Co., 206 Cal. App. 2d 780, 787, 24 Cal. Rptr. 161, 165 (1962) (attorney "in full charge of his client's cause or defense"); Board of Comm'rs v. Younger, 29 Cal. 147, 149 (1865) ("So long as he remains attorney of record the Court cannot recognize any other as having the management of the case."); see also MODEL RuLEs, supra note 36, Rule 1.2 comment 1 (1983) ("the lawyer should assume responsibility for technical and legal tactieal issues, but should defer to the client regarding such questions as the expense to be incurred and concern for third persons who might be adversely affected"). See generally 2 F. MECHEM, supra note $2, \S 2160$ (client may not interfere with "due and orderly conduct" of a case); Spiegel, Lawyering and Client Decision-making: Informed Consent and the Legal Profession, 128 U. PA. L. REv. 41, 50-60 (1979) (discussing cases holding that attorney has authority to act inconsistently with client's instructions). 
only if the principal has "the right to control the conduct of the agent with respect to matters entrusted in him."40 Imphicit in this right to control is the idea that the agent has a duty to obey the principal's instructions. ${ }^{41}$ Both the judicial decisions excluding the chent from the decision-making process in procedural matters ${ }^{42}$ and the research justifying that exclusion ${ }^{43}$ indicate that the attorney has no such duty to obey in the procedural context. Thus, the attorney more closely resembles an independent contractor than an agent. ${ }^{44}$

40. Restatement (SECOND) OF AGeNCY § 14 (1957); see also Lane v. Hopfeld, 160 Conn. 53, 59, 273 A.2d 721, 723-24 (1970) (out-of-state manufacturer had no agent in state for purposes of service of process); Gross Inconne Tax Div. v. Fort Pitt Bridge Works, 227 Ind. 538, 546, 86 N.E.2d 685, 689 (1949) (independent subcontractor acts as agent for prime contractor); N \& G Constr., Inc. v. Lindley, 56 Ohio St. 2d 415, 417, 384 N.E.2d 704, 706 (1978) (contractor as agent of owner); Siskin v. Johnson, 151 Tenn. 93, 98, 268 S.W. 630, 631 (1925) (defendant's enployee not considered agent when defendant exercised no control over activities of employee).

41. See Rianda v. San Benito Title Guar. Co., 35 Cal. 2d 170, 173, 217 P.2d 25, 27 (1950) (en banc) (principal's instructions determine duty of agent as escrow holder); Dougherty Distillery Warehouse Co. v. Binenstock, 293 Pa. 566, 569-70, 143 A. 195, 197 (1928) (agent's actions exceeding scope of authority in sale of whiskey certificates not binding upon principal); RESTATEMENT (SECOND) OF AGENCY \& 385.

42. See supra note 39.

43. See supra note 37.

44. For the distinction between an independent contractor and an agent, see Gross Income Tax Division, 227 Ind. at 546,86 N.E.2d at $689 ; N \& G$ Construction, 56 Ohio St. $2 \mathrm{~d}$ at 417,384 N.E.2d at 706 (agent subjeet to principal's control, but independent contractor employed to achieve objective, not subject to employer's control).

Some courts have held that a person nay not be both an independent contractor and an agent at the same tine. See, e.g., Jeff-Cole Quarries, Inc. v. Bell, 454 S.W.2d 5, 14 (Mo. 1970); Crist Sod Co. v. Bruce, 599 S.W.2d 43, 45 (Mo. Ct. App. 1980). Most courts, however, recognize that the terns are not mutually exclusive. See, e.g., CBS v. Stokely-Van Camp, Inc., 522 F.2d 369, 375 \& n.14 (2d Cir. 1975); Ackert v. Ausinan, 29 Misc. 2d 962, 967, 218 N.Y.S.2d 822, 827 (Sup. Ct. 1961), aff'd, 20 A.D. 850, 247 N.Y.S.2d 999 (1964); accord RESTATEMENT (SECOND) OF AGENCY $§ 14$ N comment a.

The most logical approach recognizes that an attorney is an agent with regard to some aspects of a representation, but an independent contractor or non-agent with regard to other aspects. Cf. Shea v. Bryant Chucking \& Grinding Co., 336 Mass. 312, 314, 145 N.E.2d 692, 694 (1957) ("A person may be an agent or a servant as to one part of an undertaking, and an independent contractor as to other parts."); Konick v. Berke, Moore Co., 355 Mass. 463, 466, 245 N.E.2d 750, 752 (1968) ("An employee while driving his own car inay be an independent contractor, even though he would be a servant when perforning other jobs."). Nevertheless, the Restatement (Second), along with the vast inajority of courts, inakes the broad assertion that an attorney is both agent and independent contractor in procedural contexts. RESTATEMENT (SECOND) OF AGENCY \$ 14N comment a.

Given the opinions holding that an attorney has exclusive control over procedural inatters, the Restatement (Second) creates an unusual and important exception to general agency law. Cominent a of section 385 relieves the attorney/agent of the duty to obey the instructions of the client/principal in procedural matters, despite section 385's own requirement that an agent obey the instructions of the principal. RESTATEMENT (SECOND) OF AGENCY $§ 385$ \& comment a. The exception is based on the general notion that "the employer will not interfere in the method of conducting proceedings which are customarily left in the control of the agent." Id. comment a. But see Parsons v. Martin, 77 Mass. (11 Gray) 111, 115-16 (1858) (broker prohibited froun following usage and custom regarding sale of stock when seller gave contrary instructions); W. BOWSTEAD, A D1GEST OF THE LAW OF 
The agency theory fails to reflect a client's lack of participation in procedural matters; further, it contravenes the long-establislied distinction between attorney discretion in procedural inatters and client discretion in substantive inatters. By superimposing agency law onto the attorney-client relationship, courts and scholars have forced themselves to create awkward exceptions to the central principles of agency law. ${ }^{45}$

\section{The Use of the Agency Theory to Justify Dismissal for WANT OF PROSECUTION}

The foregoing discussion lias sliown how the agency theory clashes with the real allocation of decision-inaking authority between attorney and client. The following two parts of this Note will slow that the agency theory is, in fact, only a convenient justification for the harsh results dictated by certain policy considerations. This part discusses the policy considerations underlying one such result, dismissal for want of prosecution; it then shows that apphications of the dismissal power are consistent with such considerations, but not with the agency theory.

\section{A. Policies Underlying Dismissal for Want of Prosecution.}

A court's power to dismiss a claim for want of prosecution is of ancient origin. ${ }^{46}$ The early cases speak of the dismissal power as a withlolding of relief: a court could refuse its assistance to a plamtiff who neglected to prosecute his claim in a timiely fashion. 47 These early courts focused on the conduct of the delaying party, emphasizing that a less than diligent party should not benefit from the court's power. This em-

AGENCY 117-18 (5th ed. 1912) ("It is the duty of every agent . . . , in the absence of express instructions, to act according to ... reasonable usage . . .."); F. MECHEM, OUTLINES OF THE LAW OF AGENCY $\S 520$ (4th ed. 1952) ("such customs and usages, however, cannot, as between the principal and the agent, overrule positive instructions to the contrary"). The mischaracterization of the attorney as an agent in procedural matters probably resulted from the early development of the agency theory at a time when courts failed to distinguish between substantive and procedural contexts for the purpose of notice. See supra notes 10-16 and accompanying text.

45. See 2 F. MЕснEм, supra note $2, \$ 2159$ (holding client responsible for attorney's management of a case is "contrary to the ordinary rules of agency").

46. See 3 W. Blackstone, Commentaries on the Laws of England *295-96. It has been generally accepted that the power to dismiss for want of prosecution is an inherent power of the court, "crystallized" by FED. R. CIV. P. 41(b). See Link v. Wabash R.R., 370 U.S. 626, 630-31 (1962); Boling v. United States, 231 F.2d 926, 927 (9th Cir. 1956). Rule 41(b) provides in part: "For failure of the plaintiff to prosecute . . a defendant may move for dismissal of an action or of any claim against the defendant." FED. R. Crv. P. 41(b).

47. See, e.g., Bancroft v. Sawin, 143 Mass. 144, 146, 9 N.E. 539, 542 (1887) (refusing to give "assistance to the plaintiff," who failed to act in a timely fashion on a bill to redeem land from a mortgage); Forster v. Thompson, 4 Dru. \& War. 303, 318-19 (Ir. Ch. 1843) (plaintiff's delay after filing bill would "disentitle him to [the court's] assistance"); see also W. BLAcksTone, supra note 46 , at $* 295-96$. 
phasis has been carried forward in the general principle that a party, "even if not at fault, should not be permitted to benefit from the wrong of her attorney." 48 This consideration is similar to the equitable "clean hands" doctrine:49 courts recognize that benefits might accrue to a party who has delayed, even if unintentionally,,$^{50}$ and that such a windfall inust be avoided, even at the cost of sanctioning an innocent chient. ${ }^{51}$

The second, closely related consideration underlying dismissal for want of prosecution is protection of the party adversely affected by the delay. Many courts, including the Supreine Court in Link, have cited protection of the opposing party as a key factor in their decisions. ${ }^{52}$ These decisions suggest that delay may inflict certain harms on the opposing party (such as deterioration of physical evidence, loss of memory, or loss of contact with witnesses) that only dismissal of the suit will redress. ${ }^{53}$

A final underlying policy concern is the desire for efficient management of the court system. This consideration, like the previous two, is of ancient origin and gave rise to the court's power to manage its docket by dismissing for want of prosecution. ${ }^{54}$ As court dockets have become increasingly crowded, this policy concern has played a inore important role in courts' decisions to dismiss. ${ }^{55}$

48. Anderson v. Air West, Inc., 542 F.2d 522, 526 (9th Cir. 1976) (Rule 41(b) involuntary dismissal upheld).

49. "There must be conscience, good faith, and reasonable diligence, to call into action the powers of the court." McKnight v. Taylor, 42 U.S. (1 How.) 161, 168 (1843).

50. Although a client may be perfectly innocent, slie may benefit if defendants, relying on the delay, destroy records, move to other occupations, terminate contact with witnesses, or do other acts that cause irreparable harm to their cases. See Anderson, 542 F.2d at 525; Pearson v. Dennison, 353 F.2d 24, 28 (9th Cir. 1965).

51. See infra notes $102-03$ and accompanying text.

52. See Link, 370 U.S. at $634 \mathrm{n} .10$ ("But keeping this suit alive inerely because plaintiff should not be penalized for the omissions of his own attorney would be visiting the sins of plaintiff's lawyer upon the defendant."); see also Reizakis v. Loy, 490 F.2d 1132, 1135-36 (4th Cir. 1974) ("lack of prejudice to the defendant" influenced reversal of district court's dismissal); Flaska v. Little River Marine Constr. Co., 389 F.2d 885, 889 (5th Cir.) (delay not excessive enough to require dismissal), cert denied, 392 U.S. 928 (1968); Reno v. International Harvester Co., 115 F.R.D. 6, 9 (S.D. Ohio 1986) (imsignificance of prejudice to defendant influenced reopening of plaintiff's case). See generally Note, Involuntary Dismissal for Disobedience or Delay: The Plaintiff's Plight, 34 U. CHI. L. REv. 922, 932-35 (1967) (discussiug appropriateness of unconditional dismissals to protect defendant's interests).

53. See Note, supra note 52, at 935.

54. See Jackson v. Sutphen, 2 Cow. 457 (N.Y. Sup. Ct. 1824); Rogers v. Garrison, 2 Cai. R. 379 (N.Y. Sup. Ct. 1805) (Livingston, J., dissenting); see also Link, 370 U.S. at 630-31 (The power to dismiss 'has generally been considered an 'inherent power,' governed not ouly by rule or statute but by the control necessarily vested in courts to manage their own affairs so as to achieve the orderly and expeditious disposition of cases.").

55. Cf. Link, 370 U.S. at 631-32 n.7 (discussing courts' attempts to establish formal procedures for dismissing stale cases in light of docket congestion). For another modern case citing court con- 
B. Applications of the Dismissal Power.

Under Federal Rule of Civil Procedure 41(b), a federal court has power to dismiss an action for want of prosecution. ${ }^{56}$ In exercising this power, a court need not consider any of the three policies noted above. ${ }^{57}$ As long as the Rule is violated, the court can order dismissal, regardless of whether the client was actually at fault. ${ }^{58}$ Thus, the agency theory seems technically consistent with Rule 41(b).

Despite Rule 41(b)'s unconditional grant of authority, however, courts do not in fact exercise the power to dismiss until evaluating the three policy concerns, and they pay only occasional hip service to agency law in this context. For example, in Carter v. City of Memphis, 59 the United States Court of Appeals for the Sixth Circuit noted its power under Rule 41(b) and Link to dismiss the plaintiff's employment discrimination claim based on his attorney's failure to comply with a pretrial order. Nevertheless, the court evaluated the coinpetmg policy concerns and reversed the dismissal without ever addressing the imphications of an agency relationship. ${ }^{60}$ In Shea $v$. Donohoe Construction Co., ${ }^{61}$ the Court of Appeals for the District of Columbia Circuit approached the problem whether to dismiss an innocent client's personal injury claim by engaging in a lengthy discussion of policy concerns. The court never considered holding the chent responsible under an agency theory and instead reversed the disimissal, stating, "We look disfavorably upon disinissals as sanctions for attorney misconduct or delay unless the client himself has been made aware of the problem, usually through notice from the trial court."62

These cases slow low little weight courts give the agency theory when exercising the power to dismiss for want of prosecution. In a typical agency relationship, the agent's negligence will be imputed to the principal based on the relationship alone. In the attorney-client relationship, however, errors of the attorney are miputed to the client only when certain policy concerns are satisfied. Although the difference in reasoning

gestion as a basis for the power to dismiss, see Quagliano v. United States, 293 F. Supp. 670, 672 (S.D.N.Y: 1968). See generally Note, supra note 52, at 935-37 (discussing merits of unconditional dismissal to clear dockets and avoid congestion).

56. FED. R. Civ. P. 41(b); see also supra note 46 (quoting the rule in part).

57. See supra notes $47-54$ and accompanying text.

58. See FED. R. Civ. P. 41(b).

59. 636 F.2d 159 (6th Cir. 1980).

60. Id. at 161. For other examples of cases in which courts had power to dismiss, but either exercised it or refused to exercise it on the basis of policy considerations, without evaluating agency issues, see Henderson v. Duncan, 779 F.2d 1421, 1423-25 (9th Cir. 1986); Blois v. Friday, 612 F.2d 938, 940 (5th Cir. 1980); Moran v. Rynar, 39 A.D.2d 718, 718-19, 332 N.Y.S.2d 138, 141 (1972).

61. 795 F.2d 1071 (D.C. Cir. 1986).

62. Id. at 1078 . 
is subtle, the difference in result is striking. If $A$ injures $B$, and $A$ is $C$ 's agent, then $B$ has a cause of action against $C$. If, however, $A$ is an attorney and $C$ a chent, then even if the relationship between $A$ and $C$ meets the saine agency-law requireinents, $B$ cannot be certain that a court will hold $C$ responsible for the delays caused by $A$.

\section{The Use of Agency Theory to Justify SANCtions for Discovery ABUSE}

Perhaps no other aspect of procedural law is analyzed as frequently as the use of sanctions to coinbat discovery abuse.63 Although Federal Rule of Civil Procedure 37 enumerates the sanctions available to a district court, ${ }^{64}$ it has done little to resolve the confusion that inany courts experience when considering whicli sanction to apply. ${ }^{65}$

As with the issue of dismissal for want of prosecution, ${ }^{66}$ courts can generally determine when to impose discovery sanctions by reference to various policy considerations. Rule 37(b) does allow a court to hold an innocent client responsible for lis attorney's discovery abuses, thus perinitting rigid application of the agency theory. In applying the Rule, lowever, courts liave not acted in a inanner consistent with the agency theory, but rather im accordance with the policies underlying the sanctioning of discovery abuse.

63. See, e.g., Brazil, The Adversary Character of Civil Discovery: A Critique and Proposals for Change, 31 VAND. L. REv. 1295, 1298-305, 1348-61 (1978); Renfrew, Discovery Sanctions: A Judicial Perspective, 67 Calif. L. Rev. 264, 272-78 (1979); Note, Rule 37 Sanctions: Deterrents to Discovery Abuses, 46 MONT. L. REV. 95, 96-98 (1985); Note, Discovery Abuse Under the Federal Rules: Causes and Cures, 92 YALE L.J. 352, 364-67 (1982) [hereinafter Note, Discovery Abuse]. The most common discovery abuses imclude failure to respond to interrogatories, see, e.g., Robison v. Transamerica Ins. Co., 368 F.2d 37, 38 (10th Cir. 1966), failure to respond to requests for production of docuinents, see, e.g., Coleman v. Smith, 814 F.2d 1142, 1145 (7th Cir. 1987), and requests for nongermane information, see, e.g., Edgar v. Slaughter, 548 F.2d 770, 771 n.1 (8th Cir. 1977).

64. The Rule, in relevant part, provides:

If a party or an officer, director, or managing agent of a party or a person designated under Rule $30(b)(6)$ or 31(a) to testify on behalf of a party fails to obey an order to provide or permit discovery, ... or if a party fails to obey an order entered under Rule 26(f), the court in which the action is pending may inake such orders in regard to the failure as are just, and among others the following: ... (C) An order striking out pleadings or parts thereof, or staying further proceedings until the order is obeyed, or dismissing the action or proceeding or any part thereof, or rendering a judgment by default against the disobedient party ....

FED. R. Civ. P. 37(b)(2).

65. See, e.g., Associated Radio Serv. Co. v. Page Airways, Inc., 73 F.R.D. 633, 636 (N.D. Tex. 1977) (attorneys who failed to produce discovery conference report should bear costs); SEC v. Los Angeles Trust Deed \& Mortgage Exch., 24 F.R.D. 460, 467 (S.D. Cal. 1959) (vacating order to strike made under Rule 37(b)); Golleher v. Horton, 119 Ariz. 604, 606-07, 583 P.2d 260, 262-63 (1970) (reversing dismissal for failure to coinply with discovery order because client not at fault); Battryn v. Indian Oil Co., 472 A.2d 937, 941-42 (Me. 1984) (trial court has discretion to impose sanctions for discovery abuse on attorney, client, or botli).

66. See supra notes 46-62 and accoinpanying text. 


\section{A. Policies Underlying Discovery-Abuse Sanctions.}

Rule 37, which governs the imposition of sanctions for discovery abuse, reflects two policy concerns. One is concern for a complete and fair adjudication of a case's merits. ${ }^{67}$ In light of this concern, the Advisory Committee on Rules stated im 1952 that the function of Rule 37 was to compel proper discovery, not to punish violators. ${ }^{68}$ This early focus on using Rule 37 to achieve "specific performance" of discovery requests is consistent with the goal of providing sufficient evidence for a full adjudication on the merits.

The other concern underlying Rule 37 is the philosopliy that a trial is "not a contest, but an endeavor to ascertain the trutli and an effort to attain justice."69 Rule 37 thus attempts to deempliasize the adversarial nature of a suit by pumishing those parties wlio abuse the discovery process. ${ }^{70}$

The tension between the two concerns is obvious. If a court focuses on reaching the merits of a case, it must tailor sanctions to facilitate complete and orderly discovery. ${ }^{71}$ If, lowever, a court focuses on curbing adversarial excesses, it must place a greater empliasis on strict compliance with the discovery rules and must tailor sanctions to deter abuse. ${ }^{72}$

In the early years of Rule 37, concern for reaching the merits of a dispute outweighed the goal of deterring abusive discovery tactics. ${ }^{73}$ Courts manifested their concern for reaching the merits by treating violations of the Rule leniently. ${ }^{74}$ For example, in SEC v. Los Angeles Trust

67. See Holtzoff, Origin and Sources of the Federal Rules of Civil Procedure, 30 N.Y.U. L. REV. $1057,1059-60$ (1955) (discussing shift away from rigidity of earlier procedural forms).

68. FED. R. Crv. P. 37 advisory committee's note. The Committee distinguislied between enforcement and punislıment based on two Supreme Court cases: Hammond Packing Co. v. Arkansas, 212 U.S. 322, 350-54 (1909) (court may compel production of necessary evidence), and Hovey v. Elliott, 167 U.S. 409 (1897) (court may not use dismissal to punish).

69. Holtzoff, supra note 67 , at 1060 (empliasis added).

70. See Note, Federal Discovery Rules: Effects of the 1970 Amendments, 8 CoLuM. J.L. \& Soc. Probs. 623, 642 (1972). In an effort to reduee adversarial tension, the Advisory Committee anended the rule, causing it to apply to "failure" to comply rather than "refusal." The Committee also altered the burden of proof by requiring fees unless the losing party could justify its actions.

71. See SEC v. Los Angeles Trust Deed \& Mortgage Exch., 24 F.R.D. 460, 466-67 (S.D. Cal. 1959) (refusing to impose harsh sanctions in order to reach merits).

72. See Note, supra note 70 , at 624 (discussing teusion between creating enforceable and effective rules that promote efficiency, and retaining enough flexibility to reach the merits of a dispute).

73. See, e.g., Note, The Emerging Deterrence Orientation in the Imposition of Discovery Sanctions, 91 HaRV. L. REV. 1033, 1034, 1039-40 (1978) [hereinafter Note, Deterrence Orientation]; Note, Sanctions Under Amended Rule 26-Scalpel or Meat-ax? The 1983 Amendments to the Federal Rules of Civil Procedure, 46 OHIO ST. L.J. 183, 192 (1985).

74. See, e.g., Dorsey v. Academy Moving \& Storage, Inc., 423 F.2d 858, 860-61 (5th Cir. 1970) ("The court, however, should not go beyond the necessities of the situation to foreelose the merits of controversies as punishment for general misbeliavior."); Robison, 368 F.2d at 39 ("The office of 37(d) is to secure compliance with discovery rules, not to punisl erring parties.") In Robison the 
Deed \& Mortgage Exchange, ${ }^{75}$ a district court explicitly addressed these competing policy considerations as it contemplated the proper penalty for a party's failure to comply in good faith with a discovery request. The court stated:

We simply do not consider the procedural point, concerning the scope of the Federal Rules and the powers of the court (although undoubtedly important), as being important enough to justify the avoidance of full hitigation of the substantive issues of the case. Therefore we are not disposed to adopt any reinedy at this time which affects the posture of the issues in this matter ... ${ }^{76}$

Over time, lowever, courts began to shift from a remedial to a deterrent approach. ${ }^{77}$ Motivated by increasingly crowded dockets ${ }^{78}$ and growing dissatisfaction with the lower courts' lenient interpretations of Rule 37,79 the Supreme Court, in National Hockey League v. Metropolitan Hockey Club, Inc., ${ }^{80}$ approved the imposition of sanctions to deter future abuses. The Court thus demonstrated its willingness to subordmate the interest of reaching the merits to that of deterring "those who might be tempted to such conduct in the absence of such a deterrent." 81

\section{B. Applications of Discovery-Abuse Sanctions.}

The recent empliasis on the deterrent effects of Rule 37 sanctions $^{82}$ lias increased the frequency and severity of sanctions, mcluding the extreme measure of dismissal. On its face, the resulting increase in dismissals reflects a willingness to hold clients responsible for their attorneys' abusive tactics and tlius suggests an application of agency principles. Nevertlieless, a close reading of the discovery abuse decisions indicates that courts impose sanctions witlout regard to agency theory.

Because the "American Rule" requires each party to pay its own

court seemed most concerned with the substantive effects of the parties' willingness to delay and discounted the trial court's impatience. Id.; see also Note, Deterrence Orientation, supra note 73, at 1038-40, and cases cited therein.

75. 24 F.R.D. at 460 .

76. Id. at 467 .

77. This shift is well-documented. See, e.g., Sofaer, Sanctioning Attorneys for Discovery Abuse Under the New Federal Rules: On the Limited Utility of Punishment, 57 ST. JoHN's L. REV. 680, 680-84 (1983); Note, Deterrence Orientation, supra note 73, at 1044-47 (1977); Note, Sanctions Imposed by Courts on Attorneys Who Abuse the Judicial Process, 44 U. CHI. L. REV. 619, 632 (1977); Adams \& Nolin, Discovery Curbed: Pretrial Abuses Now Punished by U.S. Courts, Nat'1 L.J., Mar. 17,1986 , at $15,18$.

78. See infra note 97 and accompanying text.

79. See supra note 74 and accoinpanying text.

80. 427 U.S. 639 (1976) (per curiam).

81. Id. at 643 .

82. See infra notes $89-91$ and accompanying text. 
litigation costs, ${ }^{83}$ a litigant has many opportunities to impose costs of litigation on its opponent through discovery abuse. The result of such abuse is to (1) externalize the abusing party's costs ${ }^{84}$ and (2) increase the settlement value of the case. ${ }^{85}$ Although most courts do not engage in a technical discussion of externalities, some courts recognize that, in order to deter discovery abuse, they must force parties to internalize the costs of discovery that benefits them. ${ }^{86}$ To enforce internalization, the courts must identify who-between attorney and chent-is responsible for the alleged abuses, and sanction that individual. ${ }^{87}$

Decisions that reflect comparative fault-finding (to compel the internalization of discovery-abuse costs) generally ignore the agency theory. ${ }^{88}$

83. See Leubsdorf, Toward a History of the American Rule on Attorney Fee Recovery, LAw \& CONTEMP. ProBs., Winter 1984, at 9 \& n.1; Note, Discovery Abuse, supra note 63, at 353-54.

84. An externalized cost is a cost created by the activities of one party and then passed off onto another party or even onto society as a whole. See A. Pigou, The Economics of Welfare 183 (4th ed. 1932). A party does not evaluate an externalized cost when deciding to engage in the activity that produces it. This leads the party to do more of the activity than is efficient. See J. Davis \& J. Hulett, AN ANalysis of Market Failure: Externaltites, Public Goods, and MIXED GOODS 8-12 (1977). Abusive tactics allow parties to externalize the costs of discovery: the abusive party can receive desired information while forcing the opponent to expend time and money to discover it firsthand. When using abusive tactics to externalize the costs of discovery, a party can decide to discover information without having to consider the real cost of obtaining it. Because parties will take full advantage of cost-free benefits, the possibility of externalization encourages litigants to create more discovery costs than are really necessary, thus reducing the overall efficiency and increasing the overall costs of the discovery process. For an excellent discussion of this phenomenon, see Note, Discovery Abuse, supra note 63, at 356-64.

85. See Posner, An Economic Approach to Legal Procedure and Judicial Administration, $2 \mathrm{~J}$. LEG. STUD. 399, 420 (1973).

86. That is, the costs of discovery must be imposed on the responsible actor herself. See Note, Discovery Abuse, supra note 63, at 364-67; see also cases cited in Adams \& Nolin, supra note 77, at 17. fault).

87. See Sofaer, supra note 77 , at $710-13$ (discussing need to sanction attorney when attorney at

88. Cases that employ the coinparative fault-finding approach and deeline to dismiss do not even address the agency issue, but instead einphasize the deterrence issue. For example, in Batson v. Neal Spelce Assocs., 765 F.2d 511, 514 (5th Cir. 1985), the court noted that a district court, before dismissal, inust consider whether the neglect was "plainly attributable to an attorney rather than a blameless client ...." The court then based its decision on the policy implications of National Hockey League v. Metropolitan Hockey Club, Inc., 427 U.S. 639 (1976) (per curiam), reh'g denied, 429 U.S. 874. Batson, 765 F.2d at 515-16. See also Butler v. Pearson, 636 F.2d 526, 531 (D.C. Cir. 1980) (vindication of judicial process and protection of litigants better served by not dismissing when client not at fault); Edgar v. Slaughter, 548 F.2d 770, 773 (8th Cir. 1977) ("When non-conpliance is the result of dilatory conduct by counsel, the courts should investigate the attorney's responsibility ...."); Ali v. A \& G Co., 542 F.2d 595, 597 (2d Cir. 1976) (Oakes, J., dissenting). As the Ali dissent stated:

the trial court should first consider the more specific and perhaps even more deterrent rem$e d y$ of imposing costs personally on the offending attorneys. Imposing a penalty on those responsible for wasting the court's time, while not dismissing a party's potentially valid claim, seems to me to inake the punishinent better fit the crime ....

$A l i, 542$ F.2d at 597 (emphasis added). 
This makes sense: if these courts applied the agency theory, they would sanction chents without apportioning blame between chents and attorneys.

Other decisions display a brute force approach to deterrence, imposing harsh sanctions on the chent in the belief that the sanction will deter future abuse and eventually reach the person at fault. ${ }^{89}$ Decisions employing this approach are not motivated by the agency theory, but rather by a strong concern with deterrence, frequently based on a real perception of chient fault. For example, in Cine Forty-Second Street Theatre Corp. v. Allied Artists Pictures Corp., 90 the Umited States Court of Appeals for the Second Circuit justified its affirmance of dismissal by citing Link and the agency theory. The court, however, inade clear that its decision was necessary "in this day of burgeoning, costly and protracted litigation," and also noted that the client was aware of and involved in every aspect of the case. ${ }^{91}$

In the context of discovery-abuse sanctions, as with dismissal for want of prosecution, altliough courts frequently cite the agency theory, the theory fails to command their consistent adherence. The modern concern for deterrence, tempered by the desire to reach the merits of a dispute, dommates the decisionmaking process. The agency theory only obscures the courts' reasoning and introduces uncertainty into the sanctioning process..$^{92}$ One can only guess the ineaning of decisions that, in a single page, cite the agency theory as a justification for sanctioning the

Cases that have affirmed dismissals using the internalization approach often cite the agency theory as a justification, but the clear message of these cases is that the suits were dismissed because of client conduct, not because of the agency theory. See, e.g., Coleman v. Smith, 814 F.2d 1142, 1147 (7th Cir. 1987) (defendants' own negligence rendered moot the issue whether gross attorney negligence could relieve defendant from default judgment); Umited Artists Corp. v. La Cage Aux Folles, Inc., 771 F.2d 1265, 1270-71 (9th Cir. 1985) (citing Link, but holding: "[i]n liglit of our conclusion tlat [the client] was partly at fault, ... we affirm the dismissal").

89. See, e.g., Tolliver v. Northrop Corp., 786 F.2d 316, 319 (7tl Cir. 1986) ("Holding the client responsible for the lawyer's deeds ensures that both clients and lawyers take care to comply."); Urban Elec. Supply \& Equip. Corp. v. New York Convention Center Dev. Corp., 105 F.R.D. 92, 99 (E.D.N.Y. 1985) (deterrent effect served by dismissal; client has remedy against attorney); see also T.E. Quinn Truck Lines, Ltd. v. Boyd, Weir \& Sewell, Inc., 91 F.R.D. 176, 182 (W.D.N.Y. 1981) ("The client is not excused from his counsel's nonfeasance unless extraordinary circumstances exist.").

90. 602 F.2d 1062 (2d Cir. 1979).

91. Id. at 1068 \& n.10; see also Damiani v. Rhode Island Hosp., 704 F.2d 12, 16-17 (1st Cir. 1983) (citing Link, but noting that "[t] he entire pattern of behavior by plaintiff's counsel casts a shadow on the bona fides of his client's case, particularly since an antitrust action requires the close cooperation of attorney and client at every stage of the lawsuit").

92. For example, in Damiani, 704 F.2d at 16, the court endorsed the agency theory as a justification for dismissal and mentioned the possibility of chent fault only in passing. Thus, althougl the court miglit have affirmed the disinissal because of client fault, the case seems to mandate consideration of the agency tleory when courts tailor sanctions for discovery abuse. 
client and then dismiss the theory as moot.93

\section{Replacing the Agency Theory With a UNIFIEd Approach TO POLICY CONSIDERATIONS}

This Note has shown that the agency theory inaccurately characterizes the attorney-client relationship and is imconsistent with the courts' real motivations in sanctioning an attorney's procedural misconduct. Indeed, the theory's relatively recent origin suggests that it developed as a convenient justification for the harsh results of giving certain policy considerations full effect. ${ }^{44}$ This analysis casts doubt on the validity of Link and decisions following the Link rule.

If courts abandoned the agency theory, they would have to replace it with a judicial mechanism that would consistently determine when to hold clients responsible for attorney errors. The appeal of the agency theory is its ease of apphication: the proper result, regardless of fault, is to sanction the client. If courts abandoned the agency theory, however, they could (and would have to) deal explicitly with the policy concerns underlying their sanctioning power. Although this approach would give the trial court wide discretion, it would also make outcomes more predictable, because parties would no longer have to guess whether a court would apply the agency theory. ${ }^{95}$

93. For example, in United Artists Corp. v. La Cage Aux Folles, Inc., 771 F.2d 1265 (9th Cir. 1985), the court stated:

By upholding the dismissal, we may be penalizing Danon more than his prior counsel. However, we have previously stated in affirming a dismissal: "it must be remembered that Appellant voluntarily chose [his attorneys] as his representative[s] in the action, and he cannot now avoid the consequences of the acts or omissions of [these] freely selected agent[s]."

In light of our conclusion that Danon was partly at fault for the failure to comply with the discovery requests, we affirm the dismissal.

Id. at 1271 (citation omitted). The court, while referring to the agency theory, thus relied upon the client's conduct to justify dismissal.

94. The agency theory's use for this purpose is not surprising. "[C]ommon sense is opposed to the fundamental theory of agency" that a primcipal is liable for the conduct of his agent. Holmes, supra note 11, at 14-15. The theory arose only from the exigencies of an indnstrialized world, see F. MECHEM, supra note 44, \$§ 352-62; Laski, The Basis of Vicarious Liability, 26 YALE L.J. 105, 111 (1916), and from the desire to compensate innocent, imjnred persous. See Limpus v. London Gen. Omnibus Co., 1 Hurl. \& C. 526, 539, 158 Eng. Rep. 993, 998 (Ex. D. 1862) ("there ought to be a remedy against some person capable of paying damages"). Thus, the agency theory has traditionally served as a legal justification for harsh and otherwise illogical resnlts. Cf. Laski, supra, at 112 (vicarious liability is "simply a legal attempt to see the individual in his social context"). Whether one finds these original purposes appropriate or not, agency rules are now positive law, cf. id. at 106 ("Nowhere has it been so difficnlt to win assent to what some have deemed fundamental dogma."), with new applications that have little to do with loss-spreading under tort law, as cases like Link make clear. When applied in these new ways, however, the rules secm hollow, im part because they are severed from their "macro" justification.

95. See supra note 27 and accompanying text. 
This Note concludes by discussing the policy considerations that should inform decisions allocating fault for procedural errors between attorney and chent.

\section{A. Deterrence and Court Congestion.}

Although the concerns of deterrence and court congestion are not identical, ${ }^{96}$ both stem from the growing backlog of civil cases. ${ }^{97}$ If the backlog results from the increased abusive activity of attorneys im each case, then courts must tailor sanctions for want of prosecution and discovery abuse to reduce that activity.

Use of the agency theory simply cannot deter delay and discovery abuse and also reduce civil case backlogs. First, deterrence requires internalization of costs, 98 and by requiring the client to bear the costs of her attorney's errors, the agency theory allows the attorney to engage in abusive activity without direct sanction, since the chent incurs the cost of such activity. Although a sanctioned, but innocent, client may bring a malpractice action against her attorney, ${ }^{99}$ the difficulty of prevailing in a malpractice action may effectively prevent internalization of the attor-

96. It is easy to imagine that a dismissal for an attorney's gross negligence miglit result in appeals or satellite malpractice litigation that could substantially repeat the underlying litigation. The deterrence interest could be served, but with increased crowding of court dockets. See Link v. Wabash R.R. Co., 370 U.S. 626, 649 (1962) (Black, J., dissenting).

97. The statistic most frequently cited as the cause of the backlog is the tremendous increase in the number of cases filed. In 1951, the number of civil cases filed in the federal courts was 41,455 . H. Hart \& H. Wechsler, The Federal CourTs and The Federal System 52 (1953). In 1960, the nuinber totaled 59,284, and in 1983, 241,842. Civil Case Backlogs in Federal District Courts: Hearings Before the Subcomm. on Courts of the Senate Comm. on the Judiciary, 98th Cong., 1st \& 2d Sess. 14 (1983-84) [hereinafter Civil Case Backlogs] (statement of Elino B. Hunter, Senior U.S. District Judge). But case filings per district court judge have actually declined since 1943. W. Mclauchlan, Federal Court Caseloads 171 (1984).

One study of the causes of the civil case backlog suggests that the delay between the filing and disposition of a given case is primarily a function of the amount of litigation activity (such as discovery and pretrial conferences) that the parties and their attorneys choose to conduct: "Stated nost sinply, cases in which lawyers and judges do inore, take longer to reach disposition." Civil Case Backlogs, supra, at 74.75 (stateinent of Deborah R. Hensler). According to Hensler's study, courts can "increase their control over the pace of litigation" by limiting the amount of litigation activity "to that which is essential to achieve an equitable resolution of the dispute." Id. at 75.

Another researcher, Steven Flanders, also believes that increased judicial control over litigation activity would help curb the backlog. S. Flanders, CASE MANAGEMENT AND CourT MANAGEMENT IN UNITED STATES DisTRICT COURTS 25-27 (1977). Flanders found that the districts with the fewest average days between filing and the end of discovery are also the districts with the most discovery requests per case. Id. at 26-27. According to Flanders, this fact, as well as the surprisingly small average nuinber of discovery initiatives per completed case, indicates that the method rather than the volume of discovery is most responsible for the delay. Id. at 27-28.

98. See supra note 86 and accompanying text.

99. Renfrew, Discovery Sanctions: A Judicial Perspective, 2 Rev. LIT. 71, 82 (1981). 
ney's costs. ${ }^{100}$ Second, even if malpractice actions provided a viable means of requiring the attorney to absorb the cost of his own errors, the satellite malpractice litigation would negate any reduction in the civil caseload.

Because clients often are not responsible for their attorneys' errors, ${ }^{101}$ courts should completely abandon the rigid agency theory and, to the greatest extent possible within the context of the primary hitigation, pinpoint the person responsible for the abuse or delay. This approach would inore effectively deter abusive discovery and delay, and would also reduce the backlog of civil cases.

\section{B. Protection of the Opposing Party's Interest.}

In contrast to the concern with reducing the civil case backlog, the interest in protecting the party potentially prejudiced by the attorney's conduct focuses only on the case at hand. ${ }^{102}$ In this context, the court may not be concerned with finding fault, but its use of the agency theory to tailor sanctions remains inappropriate. If, for example, an attorney failed to prosecute diligently, causing vital evidence to deteriorate, the only means of protecting the opposing party might be to dismiss the case, despite the client's innocence. If, however, the delay only caused a monetary loss, the proper sanction under an internalization approach would be to impose costs on the attorney. ${ }^{103}$ Neither the comparative-fault approach nor the agency theory suggests the remedy that best protects the prejudiced party's interests. Courts can find that remedy only by considering the practical effect of each available sanction on the prejudiced party.

\section{Adjudication of the Merits.}

The agency theory is also inappropriate in promoting the Federal Rules' general policy of providing full adjudication of the merits, ${ }^{104}$ since a strict application of the agency theory could easily deprive an innocent

100. See Note, supra note 24, at 867-68 (attorney has all of client's defenses as well as his own, in addition to intimate knowledge of client's affairs).

101. See Rothman, Excessive Discovery: A Client's View, 1984 Trial Law. Guide 304, 304-08 (client generally unaware of discovery abuses).

102. See generally Scott, Two Models of the Civil Process, 27 STAN. L. REv. 937, 937-40 (1975) (distinguishing between the Conflict Resolution Model and Behavior Modification Model).

103. This was precisely the approach of the early English courts. See supra note 15 and accompanying text.

104. See Holtzoff, supra note 67 , at $1059-60$. 
client of a meritorious claim. ${ }^{105}$ A court, however, can best promote its interest in adjudicating the merits by pinpointing the person at fault. Only when the client is at fault is the dismissal justified; otherwise, the attorney should be sanctioned and the case allowed to proceed. ${ }^{106}$

\section{Attorney-Client Privilege.}

Few cases liave addressed the inlerent tension between the attorneyclient privilege ${ }^{107}$ and the need to pinpoint the person at fault. ${ }^{108} \mathrm{~A}$ court's atteinpt to determine precisely who is at fault, without resorting to a separate action, could lead to an awkward and potentially prejudicial situation in which the client can waive the privilege, but the attorney cannot. ${ }^{109}$ Only if the client brings a separate action against the attorney can the attorney reveal privileged information to defend herself. ${ }^{110}$ Thus, after the court reviews all available evidence and determines that the attorney-client privilege protects the evidence required to determine fault, the court must subordinate its interests in determining fault and hold the client responsible for the attorney's errors. ${ }^{111}$ This does not inply, however, that upholding the attorney-client privilege requires using the overbroad agency theory. A case-by-case determination of the available evidence would protect the attorney-client privilege while also promoting the other interests served by pinpointing fault.

\section{CONCLUSION}

Perhaps courts still mention the agency theory when sanctioning innocent clients in order to impute a certain amount of culpability to the clients. Such a rationale inakes harsh results seem less harsh. Nevertheless, the agency theory lias never provided an accurate characterization

105. See, e.g., Townsend v. Gray Line Bus Co., 767 F.2d 11, 19 (1st Cir. 1985). Although the Townsend court noted that the client may have been guilty of serious neglect, it appeared willing to deprive an innocent client of an otherwise meritorious claim. Id. at 18-19.

106. See N.Y. Civ. Prac. L. \& R. $\$ 3042$, at 1977 comment C3042:16 (McKinney Supp. 1988).

107. See MOdel Rules, supra note 36, Rule 1.6 (1983).

108. The issue arose in Custom Craft Carpets, Inc. v. Miller, 137 Cal. App. 3d 120, 187 Cal. Rptr. 78 (1982), in which a California appellate court stated: "[w]ithout invading the attorney-client privilege, we have no means of determining whether it was the client or counsel who was responsible for pressing this litigation and imposing on both the trial and appellate courts." Id. at 123,187 Cal. Rptr. at 80 . The court affirmed the sanctions imposed on the client, reasoning that the client benefited from the delay and could obtain relief, if appropriate, from the attorney in another forum. Id., $186 \mathrm{Cal}$. Rptr. at 80.

109. See Comment, Settling a Case: A Court's Inherent Power to Impose Sanctions Before and After Eash v. Riggins Trucking, Inc., 38 RuTGers L. REv. 539, 551 (1986).

110. Model Rules, supra note 36, Rule 1.6(b)(2).

111. For an example of this approach, see Custom Craft, $137 \mathrm{Cal}$. App. 3d at 123, $187 \mathrm{Cal}$. Rptr. at 80 . The approach is logical, given the client's (less than optimal) opportunity to bring a malpractice action, in which the attorney could defend herself with privileged information. 
of the attorney-client relationship. Its recent origins in the procedural context suggest that it arose for reasons other than logical necessity. Moreover, it is inconsistent with the substance/procedure distinction in attorney authority. Finally, it clashes with the policy concerns involved in want-of-prosecution and discovery-abuse cases.

For the sake of consistency, predictability, and clarity of reasoning, courts should abandon the agency theory and rely directly on the policy concerns involved in deciding whether to sanction a less than diligent attorney or a relatively innocent client. In Cardozo's words: "Few rules in our tine are so well established that they may not be called upon any day to justify their existence as means adapted to an end."112

William R. Mureiko

112. B. Cardozo, The Nature of the Judicial Process 98 (1921). 